\title{
AMERICAN IMMIGRATION POLICY: HOW STRAIT THE GATE?
}

\author{
Franklin S. Abrams*
}

I

\section{INTRODUCTION}

As of the date of this writing, the executive branch and Congress seem to have arrived at a consensus concerning the need for change in the immigration field. Two separate bills were introduced in the 97 th Congress ${ }^{1}$ which proposed major changes in current law, including imposing sanctions against employers of "undocumented aliens," a pilot temporary worker program for Mexicans, ${ }^{3}$ and some form of amnesty for longtime undocumented aliens.

The proposed changes are designed to remedy problems perceived to be caused by immigration in the areas of population, labor markets, refugees and foreign policy. Many of these problems, however, may be more perceived than real. Moreover, many of the proposed solutions will have an impact far beyond the problems which they are designed to eliminate. This paper analyzes those solutions that may be available to help meet the problems of today's immigration, with primary focus on how the existing structure can be improved to fulfill its purpose.

This article first reviews the history behind the existing immigration law. It next analyzes the current immigration situation and its causes, and then studies the effects of immigration on labor markets, population, foreign policy and refugee problems. The article concludes with an examination of the desirability of change in our present immigration policy and law.

Copyright (C 1983 by Law and Contemporary Problems

* Attorney, Abrams \& Abrams, P.C., New York, New York.

1. The so-called "Reagan administration bill" was introduced as S. 1765 and H.R. 4832, 97th Cong., 1st Sess., 127 Cong. Rec. S11991, H7729 (daily ed. Oct. 22, 1981). The Simpson-Mazzoli bill was introduced as S. 2222 and H.R. 5872, 97th Cong., 2d Sess., 128 CoNG. ReC. S2216, H940 (daily ed. Mar. 17, 1982). The Senate bill, S. 2222, was enacted by the full Senate on August 17, 1982 by an 80-19 margin in the roll call. 128 CONG. REc. S10618-19 (daily ed. Aug. 17, 1982). The House bill died in the waning hours of the session. The Senate bill was reintroduced in the 98th Congress as S. 529, Feb. 17, 1983; the House bill was reintroduced as H.R. 1510.

2. The frequently used term "illegal alien" has negative connotations, so this paper will use the neutral, although euphemistic, term "undocumented" to denote an alien in the United States without authorization.

3. This proposal, discussed infra, is in the administration bill but not in the Simpson-Mazzoli bill. See infra text accompanying notes 129-37. 


\section{STATUTORY BACKGROUND}

Immigration to the United States was unrestricted until the late 19th century, although currents of nativism were evident in the colonial and early national eras. ${ }^{4}$ The first attempts at control were of a qualitative nature, barring criminals, prostitutes, paupers and other undesirables. ${ }^{5}$ At the same time, nativist sentiments emerged in the Chinese Exclusion Act of 1882, ${ }^{6}$ which was expanded in 1907 to exclude the Japanese as well." As nativism reached a climax during and after World War I, a quota system was instituted to preserve the "Anglo-Saxon" nature of the country. ${ }^{8}$ In this system's final form, ${ }^{9}$ which went into effect in 1929 and lasted until 1965, admission of immigrants from each country was based on the proportion of the U.S. population with that "national origin." Obviously, this statutory formulation favored-and was intended to favor ${ }^{10}$ - the northern and western European nations.

Meanwhile, immigration from the Western Hemisphere (the "back door") remained unrestricted numerically. ${ }^{1}$ When World War I impeded ocean traffic and therefore immigration, Mexicans flocked to jobs in the Southwest and Chicago, French-Canadians to New England, and Cubans and other Caribbean Islanders to the Southeast. At the same time, blacks from the American South started their massive migration northward. The Mexican migration was institutionalized in the 1940's as the bracero program, a program of government-sponsored contracts in agricultural and railroad employment. ${ }^{12}$

The first major postwar immigration legislation was the McCarran-Walter Act of $1952^{13}$ which retained the national origins quota system for immigrants from the Eastern Hemisphere and unrestricted immigration from the Western Hemisphere. Within the quotas for the Eastern Hemisphere, fixed percentages were reserved for workers with needed skills, and any remaining visas were available to

4. George Washington and THE FEDERALIST both enunciated nativist sentiments. See C. KEELY, U.S. Immigration: A POLICy ANalysis 8-10 (1979).

5. The Act of March 3, 1875, ch. 141, 18 Stat. pt. 3, 477, barred convicts and prostitutes. The Act of August 3, 1882, ch. 376, 22 Stat. 214 , also excluded "any person unable to take care of himself or herself without becoming a public charge," as well as any "lunatic" or "idiot."

6. Act of May 6, 1882, ch. 126, 22 Stat. 58.

7. Act of Feb. 20, 1907, ch. 1134, 34 Stat. 898.

8. First Quota Act, ch. 8, 42 Stat. 5 (1921).

9. Immigration Act of 1924, Pub. L. No. 139, 43 Stat. 153. The effective date of the national origins quota system was postponed on two occasions by joint resolutions of Congress. At first it was deferred until July 1, 1928, Act of March 4, 1927, ch. 514, 44 Stat. 1455, and then to July 1, 1929, Act of March 31, 1928, ch. 306,45 Stat. 400 .

10. M. Bennett, American Immigration Policies: A History 47-53 (1963). See also N.Y. Times, March 1, 1924, at 12, col. 7 (letter to the editor regarding the fairness of proposed quotas based on the 1890 census).

11. Section 4 of the Immigration Act of 1924 includes aliens born in Western Hemisphere countries as nonquota immigrants exempt from numerical limitations. 43 Stat. 153, 155.

12. These executive agreements were permitted by the ninth proviso of $\S 3$ of the Immigration Act of 1917 , ch. 29, 39 Stat. 874-76, as exceptions to the provisions banning contract labor. The executive agreemeint of August 4, 1942 with Mexico was given legislative sanction in the Act of April 29, 1943, ch. 82, 57 Stat. 70 .

13. Immigration and Nationality Act of June 27, 1952, Pub. L. No. 414, 66 Stat. 163. 
relatives of U.S. citizens, legal residents, and "new seed"-immigrants with neither family connections in the United States nor needed skills. In practice, the undersubscribed countries in northern and western Europe had a large number of visas available for new seed immigrants, whereas the oversubscribed countries in southern and eastern Europe and Asia had no visas at all in this category, and had long waiting lists in the family and worker categories as well. ${ }^{14}$

Partial relief was not long in coming. The Refugee Relief Act of $1953^{15}$ admitted 189,000 persons outside the quota restrictions. In addition, 40,000 Hungarians were admitted to the United States in the years 1956 to 1958, following political unrest in Hungary. ${ }^{16}$ In 1957, 300,000 visas which had been "borrowed" from the future by the Displaced Persons Act of 1948 were restored to the countries involved, and 57,000 additional visas were provided. ${ }^{17}$ Altogether, between 1952 and 1965, 3,500,000 immigrants were admitted, two-thirds of whom were admitted outside the regular quota system. ${ }^{18}$

While nativists retained the basic quota system and anti-nativists riddled it with exceptions, the back door remained open. The need for migrant labor at harvest time, together with evidence that the large majority of Mexican and other Western Hemisphere laborers constituted a rotating stock of migrant laborers rather than a permanent stock of immigrants, combined to override temporarily the fear that leaving the back door open with only qualitative restrictions would pave the way for a massive increase later.

By 1965 it became clear that the national origins system had to be scrapped. The Cold War was apparently over and the advocates of increased immigration (ethnic groups, the "liberal" wing of the Democratic Party, agri-business, employers, religious groups, liberal unions anxious for new members, such as the International Ladies' Garment Workers Union, and idealists in general) triumphed over their opponents (those labor unions fearful of the potential undercutting of wages and working conditions, nativists, and some American minority groups). ${ }^{19}$

Under the 1965 Act, ${ }^{20}$ each country in the Eastern Hemisphere was provided with a maximum annual quota of 20,000 . Overall, the bill greatly favored family

14. M. BENNETT, supra note 10 , at 212-39.

15. Act of Aug. 7, 1953, Pub. L. No. 203, 67 Stat. 400.

16. The Presidential directives of November 8, 1956 and December 1, 1956 authorized the parole of Hungarians into the United States. In addition, the Presidential statement of November 8 specifically directed the administrator of the Refugee Relief Act to process up to 5,000 Hungarians as refugees. Finally, the Presidential announcement on December 1 offered asylum to 15,000 as "parolees" and raised the number to be admitted as refugees to 6,500 for a total of 21,500 . Statement by the President Concerning the Admission of Refugees From Hungary, 1956 PuB. PAPERS 1093 (Nov. 8, 1956); White House Statement Concerning the Admission of Additional Hungarian Refugees, 1956 PUB. PAPERs 1116 (Dec. 1 , 1956).

17. Act of Sept. 1957, Pub. L. No. 85-316, 71 Stat. 639.

18. A. Zolberg, The Main Gate and the Back Door: The Politics of American Immigration Policy, 1950-1976, at 19 (April 12, 1978) (prepared as a background paper for the April 12, 1978 meeting of the Study Group on Immigration and U.S. Foreign Policy, Council on Foreign Relations). For the yearly figures see $\$ 3$ of the annual issues of the STATISTICAL ABSTRACT OF THE UNITED STATES between 1952 and 1965 .

19. A. Zolberg, supra note 18 , at $30-32$.

20. Immigration Act of 1965, Pub. L. No. 89-236, 79 Stat. 911. 
reunification, with $74 \%$ of the visas allocated to family members, $20 \%$ to workers, and $6 \%$ to refugees from communism or from the Middle East. ${ }^{21}$ In addition, spouses and minor unmarried children of U.S. citizens and parents of adult U.S. citizens were admitted entirely outside of the quota restrictions, and amounted to an additional 100,000 immigrants per year. ${ }^{22}$ In practice, the supply of visas during the early years exceeded demand, and thousands of visas were available each year for "nonpreference" applicants. Organized labor, however, succeeded in writing into the 1965 law a strong protection against these new seed immigrants. Under the $1952 \mathrm{Act}$, all immigrants not entering under family reunification categories could be admitted unless the Secretary of Labor certified that they were taking the jobs of Americans. ${ }^{23}$ This policy was reversed in 1965. The new act stated that an immigrant not covered by a family reunification preference had to obtain a positive certification from the U.S. Department of Labor that he was not taking the job of an American. ${ }^{24}$ This labor certification provision applied not only to all immigrants arriving under the worker preferences, but also to nonpreference or new-seed applicants seeking to enter the labor market. Virtually the only exceptions to this provision consisted of aliens coming to invest in businesses in the United States and elderly persons with means of support (usually parents of legal residents, who were somehow left out of the preference system). ${ }^{25}$ Unfortunately, by the 1970's, demand had increased to fill the preference categories, and, as a result, this nonpreference category (investors and parents of residents) has been effectively closed for several years. ${ }^{26}$

The total annual worldwide quota was set in 1965 at 290,000 - a version of the "magic number" of one-sixth of $1 \%$ of the U.S. population. ${ }^{27}$ This formula-one immigrant for every 600 Americans-had first appeared in the 1924 quota law. ${ }^{28}$ One-sixth of $1 \%$ of the 1960 population of $180,000,000$ would have been 300,000 , and to this figure the immediate relatives of U.S. citizens as well as the Western Hemisphere immigrants were orginally intended to be added without limit. But during the 1950's, increased Western Hemisphere immigration-legal and illegal-made clear the necessity of limiting access through the back door. Limits were established in 1965 at 170,000 for the Eastern Hemisphere and 120,000 (a

21. Id. at 912-15. The amendment to the act allocated the numerically limited visas for Eastern Hemisphere natives as follows: first preference (20\% of the total) to unmarried sons and daughters of American citizens; second preference ( $20 \%$ plus any visas unused by the first preference) to spouses and unmarried sons and daughters of legal permanent residents of the United States; third preference (10\%) to members of the professions; fourth preference (10\% plus any visas unused by the first three preferences) to married sons and daughters of American citizens; fifth preference ( $24 \%$ plus any visas unused by the first four preferences) to brothers and sisters of American citizens; sixth preference (10\% of the total) to nonprofessional workers. Qualified refugees were allocated the remaining $6 \%$, and any unused visas were available to qualified "nonpreference" applicants.

22. Id. at $917-18$.

23. Immigration and Nationality Act of June 27, 1952, Pub. L. No. 414, 66 Stat. 163, 183.

24. 79 Stat. 917-18.

25. 8 C.F.R. $\$ 212.8(b)(1982)$ (investors were exempted by this regulation, while elderly persons were presumed not to be entering the labor market).

26. The Monthly Bulletin of the Visa Office (now Visa Services), United States Department of State, has shown an unavailability of nonpreference visas since 1978.

27. A. Zolberg, supra note 18 , at $28-29$.

28. Immigration Act of 1924, Pub. L. No. 139, 43 Stat. 153, 159. 
stingy version of the 130,000 averaged by the Western Hemisphere during the preceding few years) for the Western Hemisphere. The result was a radical and liberalizing change in national origins, coupled with a conservative increase in numbers. This setback for the employer groups favoring admission of labor from Latin America was, however, only a paper defeat. Perhaps the employer groups knew that the 120,000 limit would not stop the entry of temporary migrants across the Mexican border. Indeed, keeping the flow illegal rather than regulated through the bracero program served agribusiness well. Employers and workers were freed from bureaucratic procedures, and workers were deprived of the opportunity to gain political power, union organization, and employee rights. This is not to imply that migrant workers were always exploited, but simply to indicate that employer interests benefited from a "system" which changed a regulated bracero flow into an unregulated "illegal" flow.

The 1965 Act remains the basis of our system today. Major changes occurred in $1976,{ }^{29}$ when the preference system was extended to the Western Hemisphere; in $1978,{ }^{30}$ when the hemispheric quotas were combined into one worldwide quota; and in 1980, with the passage of the Refugee Act. ${ }^{31}$ This latter Act allowed entry of refugees as defined by the United Nations ${ }^{32}$ - those who have a well-founded fear of persecution because of race, religion, nationality, membership in a particular social group, or political opinion-instead of limiting refugee status to those fleeing communism or the Middle East. Up to 50,000 refugees may be admitted each year, although the President may increase the number. ${ }^{33}$ The 1980 Refugee Act also reduced the rest of the worldwide quota from 290,000 to 270,000, again exclusive of immediate relatives of U.S. citizens. ${ }^{34}$

\section{III}

\section{The Present Situation and Its Causes}

With the statutory background in mind, one may consider the realities of the present situation. The flow of immigration to the United States is part of a worldwide movement which includes refugees, ${ }^{35}$ "economic refugees," and others who wish to change their residence, either temporarily or permanently. With the tremendous population increase in the so-called Third World, the ongoing revolutions in transportation, communication, and urbanization, and the usual number of international conflicts creating refugees, it was to be expected that the absolute number of migrants would increase dramatically. In every Third World country, motion pictures and sometimes television exhibit the attractions of First World countries, and the jet plane puts even the most distant places in the world only a

29. Immigration and Nationality Act Amendments of 1976, Pub. L. No. 94-571, § 2, 90 Stat. 2703.

30. Act of Oct. 5, 1978, Pub. L. No. 95-412, 92 Stat. 907.

31. Refugee Act of 1980, Pub. L. No. 96-212, 94 Stat. 102 (codified in scattered sections of 8 U.S.C.).

32. Convention Relating to the Status of Refugees, July 28, 1951,189 U.N.T.S. 150, 152; Protocol Relating to the Status of Refugees, Jan. 31, 1967, 19 U.S.T. 6223, T.I.A.S. No. 6557, 606 U.N.T.S. 267.

33. 8 U.S.C. $\$ 1157$ (a)(1) (Supp. IV 1980).

34. Id. at 8 U.S.C. $\S 1151$ (a) (Supp. IV 1980).

35. In this context, the term is used as defined in the U.N. Convention and Protocol, supra note 32, and does not include those migrating for economic reásons. 
day's flight away. ${ }^{36}$

Of all the First World countries, the United States currently receives twice as many refugees and immigrants as the rest of the world combined. In 1980, legal immigrants totalled over $800,000 .{ }^{37}$ This figure was swelled by approximately 130,000 Cuban and Haitian "entrants" specially admitted; but even without them, the number is comfortably above the 526,000 admitted in 1979.38 The United States is the most popular destination partly because it is the only one available to many immigrants, since European countries have in large measure terminated their guestworker programs. ${ }^{39}$ Only the United States remains relatively open to legal immigration-not to mention the opportunities for "unofficial" immigration available to those who avoid the Immigration and Naturalization Service (INS) entirely.

It is not presently known how many aliens reside in the United States and whether their number is increasing or decreasing. The 1980 census counted about $15,000,000$ "Hispanics" in the United States, ${ }^{40}$ but obviously missed many undocumented aliens. INS statistics are suspect both because they count occurrences rather than persons (some of whom may be picked up several times in one year), and because the INS concentrates its enforcement on the Mexican border (and thus $90 \%$ of those apprehended are Mexicans). ${ }^{41}$ Ellen Sehgal and Joyce Vialet ${ }^{42}$ sum up the recent estimates of the undocumented population as ranging from $2,900,000$ to $5,700,000$, and put their own estimate at 3,900,000. Charles Keely ${ }^{43}$ puts the range at $3,500,000$ to $5,500,000$. Both estimates are far below the "panic" figures of five years ago ${ }^{44}$ and, as Wayne Cornelius points out, ${ }^{45}$ it is unknown how many of the aliens are temporary and how many are permanent. If the population is composed of a rotating group of temporary workers, the policy responses may have to be different. Also, since little is known about the age, sex, and fertility of the undocumented population, the natural rate of increase cannot

36. Migration is both an individual response to perceived stimuli and, taken collectively, a social movement with an impact on both the sending and receiving societies. It is, nevertheless, regulated in most cases only by the receiving societies. While sending societies welcome the loss of unemployed less skilled workers they have complained about the so-called "brain drain." This paper leaves this topic to others; much recent research indicates that sending countries do not suffer any net loss through emigration of skilled persons whom, in many cases, they cannot employ. See Nagarajan, The Brain Drain Problem and Human Rights, 8 Migration TOday 19, 21 (No. 5, 1980).

37. Immigration and Naturalization Service statistics, cited in TIME, May 18, 1981, at 24.

38. Id.

39. Hewlett, Coping with Illegal Immigrants, 60 For EIGN AfF. 358, 370 (1981).

40. N.Y. Times, June 28,1981 , at 1 , col. 3.

41. Annual Reports of the Immigration and Naturalization Service since 1974 indicate that roughly 90\% of apprehensions are of Mexicans. Statistical ABSTRact OF THE United States 92 , Table 142 (1981).

42. Sehgal \& Vialet, Documenting the Undocumented: Data, Like Aliens, are Elusive, 103 MONTHLY LAB. REV., Oct. 1980, at 18.

43. C. KEELY, supra note 4, at 51; Keely, Illegal Immigration, SCI. AM., Mar. 1982, at 41.

44. At that time, the Commissioner of the Immigration and Naturalization Service, Leonard Chapman, estimated that there were between 4,000,000 and 12,000,000 undocumented aliens in the United States. Other mid-1970's estimates cited in Professor Keely's Scientific American article are 6,000,000 and 8,200,000. Keely, supra note 43, at 41-42.

45. W. Cornelius, Mexican Immigration to the United States: Causes, Consequences, AND U.S. RESPONSES 12, 13 (1978). 
be predicted. Even more striking, it is not known whether the total number of undocumented aliens is growing, although this does not appear to be the trend. ${ }^{46}$ If the figures cited by Keely and Sehgal are to be believed, the "illegal alien crisis" is not really a crisis at all; the numbers are substantial but not growing and, therefore, the situation is certainly not out of control. Perhaps the illegal alien problem should be viewed merely as an integral part of the entire immigration picture-not even the largest part-and the undocumented population should be considered as a group of people who may or may not become permanent residents. Many do obtain legal status eventually, either by marriage or through a parent or sibling who has acquired American citizenship, or by labor certification. The illegal alien population thus includes many who are only temporarily in illegal status.

Whatever the exact numbers, the chief sources of the demand for immigration to the United States are the crowded countries of Asia and Latin America. In fiscal 1980 the chief sending countries were Mexico, Vietnam, the Philippines, Cuba, Korea, China, India, the Dominican Republic, and Jamaica. ${ }^{47}$ In addition, 168,000 Indochinese refugees, 117,000 Cuban "entrants," 50,000 refugees from the Soviet Union and eastern Europe, and 15,000 Haitian "entrants,"48 were admitted, though not yet for permanent residence.

According to demographers, Asia's population of 2,400,000,000 will double in 36 years, ${ }^{49}$ and Mexico will add $60,000,000$ in the next 20 years. ${ }^{50}$ Mexico will need 700,000 jobs per year, but that country's official forecast is that it will offer only 350,000 jobs, if all goes well. ${ }^{51}$ Thus, the trends do not augur well for a diminution of the demand to enter the United States. Furthermore, in the countries which have contributed principally to the recent flow, there is no reason to assume that even a slowing of population growth would have much impact on the demand for immigration to the United States. First, many of the immigrants from Asian countries are just now developing an infrastructure of restaurants, small businesses, and ethnic support organizations in this country, which makes migration for later entrants much easier than it was for the earlier pioneers. Such development is likely to encourage more migration from those Asian countries. Second, the number of countries to which persons could migrate is diminishing. For example, Indians have had a long history of migration to the Near East, the West Indies, Africa, and more recently to the United Kingdom, the United States, and Canada. With many of these other receiving countries now closing their doors to immigrants or even expelling them (e.g., Uganda), the United States clearly remains the most attractive destination. Moreover, the race relations climate in the United States, however poor it may seem to some here, is viewed by aliens as the most

46. A. Corns, Coverage Issues Raised by Comparisons of CPS and Establishment Employment (paper presented at the 1977 meeting of the American Statistical Association), cited in C. KEELY, supra note 4, at 52.

47. Newsday, June 7,1981 , at 4 , cols. 2,3 .

48. Id.

49. Graham, Illegal Immigration and the Lef, 27 DiSSENT 341 (1980).

50. Teitelbaum, Right versus Right: Immigration and Refugee Policy in the United States, 59 ForeIGN AFF. • 21, 29 (1980).

51. Id. 
benign in the Western World. Indians are consequently seeking to relocate here from countries of first settlement, such as the United Kingdom. Finally, the factor of physical climate should not be overlooked. For instance, although Canadians have been relatively receptive to immigration, their harsh winters are especially difficult for immigrants from warm climates.

The Chinese have a similarly long history of out-migration. Whether closer Sino-American diplomatic ties will have any effect on an already high rate of immigration to the United States remains to be seen. Certainly, the opening of U.S. consulates can only make the process easier. ${ }^{52}$

Other Asian nations, such as Korea and the Philippines, have close ties to the United States and a history of substantial migration since the 1965 Act made migration possible. ${ }^{53}$ Although economic factors in the Philippines may play a role in fostering immigration to the United States, the political climate there and in Korea also plays a part. ${ }^{54}$ In addition, links forged by wars have made Filipinos and Koreans especially fond of the United States.

It follows that demand for immigration to the United States depends not only on objective factors, but also on intrinsic patterns which have developed over generations. Thus, that demand is likely to continue no matter what is done about economic growth and population control. In fact, with the exception of India, the Asian countries sending the most immigrants to the United States-China, Korea, and the Philippines-are not by any means the most needy of the world's nations. 55

Latin America is perhaps a more pure example of economic and demographic forces at work. The predictions for population growth there are so frightfully high that even massive development aid, correctly focused, would have only an insignificant positive effect on the economic growth rate. There are simply too many people of child-bearing age and too many children already born who will be looking for jobs within the next ten or twenty years.

On the other hand, Michael Piore ${ }^{56}$ argues that immigration demand is governed not by the characteristics of the migrants or by incomes or population pressures at the place of origin, but rather by the structure of the jobs available in the United States; that is, migrants come to fill specific slots in the American economy. To the extent that this argument is correct, a discussion of population pressures in the Third World is rendered irrelevant in predicting future demand for immigration to the United States. That the argument is at least somewhat credible is evident from the fact that very few undocumented workers are unemployed. Afraid to

52. In addition, the International Security and Development Cooperation Act of 1981, Pub. L. No. 97-113, § 714, 95 Stat. 1519,1548 (codified as amended at 8 U.S.C. $§ 1152$ (1976 \& Supp. V 1981)), sets up a 20,000 per year quota for Taiwan which is separate from the 20,000 per year quota for mainland China, thus effectively doubling the Chinese quota.

53. Annual Reports of the INS show both countries reaching the 20,000 per year limit consistently since 1965.

54. Both countries have suffered varying degrees of political repression in recent years.

55. The GNP per capita for several African and Asian countries is significantly below $\$ 200$. In comparison, the per capita GNP is $\$ 410$ in China, $\$ 671$ in South Korea, $\$ 415$ in the Phillippines, and $\$ 1074$ in Taiwan. V. Showers, WORLd FaCts AND Figures, 333-39, Table 10c (1979).

56. Piore, Another View on Migrant Workers, 27 Dissent 347 (1980). 
apply for unemployment insurance if they cannot work and ineligible for welfare, unemployed undocumented workers return home, where family and kinship group support is available.

Finally, it might be wise to question the assumption that immigration to the United States is a "safety valve" for Third World countries (especially Mexico) staving off revolution. Otis Graham ${ }^{57}$ claims that U.S. tolerance of large-scale immigration is in effect a subsidy to the Mexican elites, enabling them to postpone indefinitely the type of redistribution of land and goods which would be necessary if many of the workers returned. Yet it is impossible to predict whether closing the safety valve would lead to revolution or to democratization, or whether it would have any effect at all. There have been no greater restrictions on immigration from El Salvador or Nicaragua than from Mexico (indeed, Salvadorans have for years entered the United States through Mexico by the thousands and comprise the second largest national group of aliens apprehended and deported for illegal entry), ${ }^{58}$ and the "safety valve" has not prevented revolutions in those two countries. If a revolution is going to occur, the availability of emigration to the United States as an alternative probably has very little effect. The members of revolutionary cadres are not the type to come to the United States anyway. As Michael Teitelbaum points out, ${ }^{59}$ this whole argument should be consigned to the "don't know" category. As for the argument that U.S. desire for Mexican oil and gas should color our immigration policy toward Mexico, it bears mention that the Mexicans, like the Saudi Arabians, will in the long run probably set their prices and allocations from self-interest anyway; U.S. immigration policy will hardly enter into their considerations. The United States does, after all, happen to be their closest and richest customer.

\section{IV}

\section{The Disputed Population Effects of Immigration}

If the world's population seems to be burgeoning incessently-regardless of any possible effect on immigration rates to the United States - what of the population of the United States? The advocates of zero population growth complain that immigration now accounts for $50 \%$ of U.S. population growth. They neglect to mention, however, that the principal reason for this percentage is that the U.S. birth rate has declined to less than the replacement level of 2.1 births per woman per lifetime. ${ }^{60}$ Although it is impossible to predict future birth rates accurately by merely extrapolating from present rates or trends, it would seem that, with greater participation by women in the labor force ${ }^{61}$ and with greater postponement of marriage to accommodate careers, it is unlikely that the birth rate in the United

57. Graham, /llegal Immigration and the New Restrictionism, CeNTER MAGAZINE, May-June 1979, at 54.

58. 1979 ANNUAL REPORT OF THE INS (available only through the Washington Office of the INS).

59. Teitelbaum, supra note 50 , at 47-48.

60. C. KEELY, supra note 4 , at 46.

61. This trend will also increase the demand for household workers, a category which, at least for the past 15 years, has been filled principally by aliens, in most areas of the country. 
States will rise much, if at all.62 Using current fertility trends, Charles F. Westoff ${ }^{63}$ has calculated that net immigration of 800,000 per year would be necessary to prevent a decline in population. If net immigration is reduced somewhat, to 400,000 per year, the U.S. population would stop growing in the year 2030 at a figure of $250,000,000$ and would begin to decline. ${ }^{64}$

The advocates of no-growth believe that the United States is already too crowded, too wasteful of energy, and too destructive of the environment. It should be mentioned, however, that most immigrants settle in our older urban centers, where infrastructures are already developed. Even with the alleged tremendous inflow of aliens, these centers lost great numbers of inhabitants between 1970 and 1980. Without the influx of immigrants, they would be wastelands. ${ }^{65}$ Furthermore, when compared to Europe, the United States is relatively uncrowded. For example, France-not the most densely populated country in Europe-is four times as densely populated as the United States. ${ }^{66}$

The opponents of immigration at current levels argue that the governmental costs of relatively free immigration are an unfair burden on the United States and especially on certain of our local governmental units. In this respect, they are probably right as to the local level, but wrong as to the national level. Julian Simon, professor of economics at the University of Illinois, ${ }^{67}$ concludes that very few aliens collect social security benefits (although this may change if an amnesty is declared), whereas $77 \%$ have social security taxes deducted, and $73 \%$ have federal income tax withheld. ${ }^{68}$

Just as the alien population is unevenly spread around the country, the burden on state and local governments is unevenly distributed. For example, the burden of health costs is severe in areas with large populations of aliens. But this burden is severe wherever a large number of poor people have access to health care. The problem and its solution are actually public health problems unrelated to immigration. The situation is similar in areas such as Texas where schooling of aliens is considered a cost problem. The undocumented worker either owns a home and

62. Wayne Cornelius also mentions the development and use of modern contraceptive techniques, increased availability of legal abortions, and rising divorce rates. W. CORNELIUS, supra note 45 , at 79.

63. Westoff, Marriage and Fertility in the Developed Countries, 239 SCI. AM. 57 (1978).

64. Westoff, Some Speculations on the Future of Mamiage and Fertility, 10 Fam. Plan. Perspectives 79 (1978). Although illegal immigration cannot be reliably estimated, it should be remembered that the majority of undocumented Mexican aliens make several trips back and forth. Therefore, the net addition to the stock of undocumented aliens cannot be enormous. Current estimates of the undocumented population average $4,500,000$, and the inflow has been large for at least 15 years. When averaged, the net addition comes to no more than about 300,000 per year.

65. For an interesting colloquy concerning the effect of immigration on the environment, see Graham, supra note 49, and Piore, supra note 56.

66. France has 252 people per square mile, while the United States has about 60 per square mile. The World Almanac 537, 592 (1982).

67. Time, May 18, 1981, at 26.

68. It would be interesting to know the comparable figures for the "underground economy" among U.S. citizens, especially those in domestic and restaurant work, day labor, and other tasks frequently performed by undocumented alien workers, before condemning the $27 \%$ of aliens who do not have taxes withheld. Ironically, sanctions against employers of undocumented workers would produce the undesirable effect of forcing more workers into the underground economy, thereby depriving the government of their tax revenues to a greater extent than at present. 
pays property taxes or occupies rented premises and provides an income for his landlord, spends his own income in the local economy (especially if he has children), and contributes his share to local tax revenues. To deprive his children of an education is both mean-spirited and ultimately destructive of the future. To the extent that a burden is placed on the local school system, it is the same burden which falls on all school systems which service a predominantly poor clientele. Just as the health cost problem presents a public health dilemma, the school problem is an educational cost problem rather than an immigration concern. ${ }^{69}$ As Wayne Cornelius points out,

[I]t is clear that discussions of the "social welfare costs" of illegal migration which fail to take account of the migrants' contributions to tax revenues provide a grossly distorted view of the "burden" imposed on U.S. society by these migrants. All available evidence suggests that they are subsidizing the system rather than draining it. ${ }^{70}$

Finally, despite popular belief, welfare costs have never been a significant problem. Undocumented aliens are far too frightened of any government agency to apply for welfare in large numbers. Legally admitted immigrants are entitled to collect welfare on the same basis as U.S. citizens. Of course, when a potential immigrant applies for his entry visa, the State Department and the INS are supposed to enforce the provision of the Immigration and Nationality Act which states that any alien "likely to become a public charge" is inadmissible to the United States. 71 The usual method for determining admissibility is to require either an offer of employment or an "affidavit of support" for any alien seeking entry. Of course, the job may be lost later, and the support is not legally enforceable. In such a case, there is no way out of the dilemma short of deporting an alien who falls into distress for any reason, a harsh and unlikely step.

Recently the law was amended to require that applicants for Supplementary Security Income (SSI) include the income of their sponsors as their own for the first five years. ${ }^{72}$ All sponsors of elderly immigrants are informed of the legal effect of their affidavits in this respect. Barring major changes in the sponsor's income, this amendment should greatly decrease the incidence of newly arrived elderly immigrants obtaining SSI immediately. Although it would be difficult to apply, a similar step could be taken with regard to applicants for welfare benefits. Rather than blame the alien for circumstances beyond his control, or do nothing and thus penalize the local area, trying to get the money from the alien's sponsors is the most sensible approach. As for the immigrant who merely loses his job, he should be treated like any U.S. citizen in similar straits.

Those who advocate restricted immigration, after mentioning the alleged demographic and adverse environmental effects, sometimes make the population argument more focused. Since $40 \%$ or $50 \%$ of the influx is from Latin America, they

69. The recent Supreme Court decision in Plyler v. Doe, 102 S. Ct. 2382 (1982), held unconstitutional a Texas statute limiting free public education to children of U.S. citizens and legal residents.

70. W. CoRnelius, supra note 45 , at 90 .

71. Immigration and Nationality Act of June 27, 1952, Pub. L. No. 1414, 66 Stat. 163, 183. This provision is, however, no longer applicable to aliens seeking adjustment of status as refugees. Refugee Act of 1980, 8 U.S.C. $\S 1154$ (c) (Supp. IV 1980).

72. Social Security Disability Amendments of 1980, Pub. L. No. 96-265, $\S 504,94$ Stat. $441,471$. 
caution that the United States might become another Canada or Belgium, with two official languages and constant ethnic strife. ${ }^{73}$ It is certainly true that there has been recent pressure for bilingual education. Whether this is because of increased immigration from Spanish-speaking countries is open to question. It may instead reflect increased pressure by an ethnic group which for decades has been relatively quiescent. In any case, the argument is an educational one, having nothing to do with numbers. In many places in the United States survival is possible without fluency in English; advancement in social and economic life, however, is impossible without it. The ability to speak English is required in almost any supervisory position or position dealing with the general public. Naturally, knowledge of Spanish is an advantage in many cases, but it is English, not Spanish, which is the necessity. Whether bilingual education is the best means to achieve English fluency is an open question to which there is no certain answer. Furthermore, it is an educational question, which is necessarily beyond the scope of an article dealing with immigration policy.

Although the immigrant inflow is largely Hispanic and would seem thus to presage greater concentration and less diversity in the immigrant population, there has also been greatly increased immigration from Asia. The cities of the United States are filled with Chinese, Koreans, Indians, and Filipinos-people who obviously look different and in many cases have vastly different religions and customs. Approximately 589,000 Indochinese refugees have been settled throughout the United States including many in small communities which until recently had had little contact with outsiders. ${ }^{74}$ Although there have been widely publicized ethnic confrontations, such as those involving Vietnamese-owned shrimp boats in Texas, ${ }^{75}$ most of these groups will eventually be integrated into the great patchwork quilt of ethnic America.

\section{The LABOR MARKet EFFECTS OF IMMigration}

If the population effects of immigration are in dispute, the labor market effects are even more hotly contested. There is fierce debate over the allegation that aliens take jobs away from U.S. citizens and depress wages and working conditions. More broadly, the question could be framed: Do aliens benefit the American economy, or are they a detriment?

Opinion on this question is divided. One side is represented by David North and Allen LeBel in their study, Manpower and Immigration Policies in the United States, ${ }^{76}$ and the other side by Wayne Cornelius in Mexican Immigration to the United

73. Teitelbaum, supra note 50 , at $42-44$; see also Hewlett, supra note 39 , at 360 .

74. Refugee Policy Group, The Geographic Distribution of Indochinese Refugees (Jan. 1983) (unpublished report by Refugee Policy Group, 1424 16th Street, N.W., Washington, D.C.). For a contrary position, see Bach \& Bach, Employment Pattems of Southeast Asian Refugees, 103 MoNTHLY LAB. ReV., Oct. 1980, at 31,35 . Latest reports place the figure around 589,000 for the total number of Indochinese refugees presently in the United States. Time, May 10, 1982, at 17.

75. N.Y. Times, Apr. 25, 1981, at 1, col. 5.

76. D. North \& A. LeBel, Manpower and Immigration Policies in the United States (National Commission for Manpower Policy Special Report No. 20, Feb. 1978). 


\section{States: Causes, Consequences and U.S. Responses. ${ }^{77}$}

North and LeBel argue that labor-intensive industries in the United States are an anachronism and that there is no need for a pool of unskilled aliens. The existence of such a pool-especially considering its members' high motivation and lack of rights-discourages employers from increasing wages and improving working conditions, inhibits unionization, and retards the introduction of labor-saving machinery. ${ }^{78}$ This benefits only the illegal workers, their employers (through higher profits), and consumers (through lower prices). Those who suffer are primarily low-income workers who cannot compete with the alien labor force. North and LeBel state that there is only slight displacement of U.S. workers by aliens and that the principal result of the current policy is a general depression of wages at the bottom of the scale. ${ }^{79}$ This creates a "secondary labor market" characterized by low wages, poor working conditions, and little chance for advancement. The pool of alien labor makes it uneconomical for employers to change the situation. North and LeBel argue that U.S. citizens would take these jobs if wages and standards were raised.

North and LeBel identify eight policy areas influenced by immigration. They assert that immigration adversely affects the ability of the United States to improve social equity through increased employment opportunities (by creating the "secondary labor market"), adversely affects the ability to achieve full employment (through displacement of U.S. workers), adversely affects the integration between income-maintenance programs and employment policies by discouraging unemployed U.S. citizens from taking "dead end" jobs, and adversely affects the skill mix of the labor force. On the positive side, immigration aids international cooperation and development, stimulates production, reduces consumer costs, and preserves endangered industry. ${ }^{80}$ Assuming, for the sake of argument, that this calculus is correct, each person must decide which goals are the more important. The latter four are certainly more far reaching.

North and LeBel concede that research does not exist to prove or disprove their assertions. ${ }^{81}$ They reason that whereas the illegal worker considers himself a temporary worker and therefore does not desire a long-term association with an employer, the U.S. citizen wants a career. Given the fact that the American generally has not suffered the poverty which the alien has, and given the availability of income transfers such as welfare and unemployment compensation, there is no incentive for the American to take a job in the "secondary labor market."

Rather than drawing the conclusion that aliens should be allowed to work on these jobs, however, North and LeBel deduce that " $[t]$ he jobs that are considered to be unattractive to American workers and that are held by illegal aliens and other aliens may not deserve to exist if they cannot be restructured to become

77. W. CORNELIUS, supra note 45.

78. D. NORTH \& A. LEBEL, supra note 76, at 158-60. North has stated elsewhere, "An illegal immigrant can't complain to the boss about his working conditions. He's less likely to join a union. Some employers actively prefer illegals because they're docile." NewswEEK, July 7, 1980, at 29.

79. D. NORTH \& A. LEBEL, supra note 76, at 158.

80. Id. at $143-44$.

81. Id. at 155 . 
acceptable to resident workers." 82 This deduction is a large leap, unsupported by research or reasoning.

Wayne Cornelius, in his study on Mexican immigration to the United States, disputes North and LeBel's conclusions concerning the labor market consequences of alien workers. ${ }^{83}$ Whereas North and LeBel assert that a reorganization of U.S. industry to eliminate the jobs in the "secondary labor market" must be accomplished immediately (principally by cutting off the supply of alien labor), Cornelius argues that the mechanization must occur first, in a gradual process. As a result, the demand for alien labor will slowly diminish, without deleterious effects on the economy. This process has already occurred in tomato and cotton harvesting which have been mechanized and no longer employ significant numbers of alien pickers. In fact, progressively fewer aliens are being employed in the agricultural sector, and more aliens are occupied in lower-level industrial jobs. ${ }^{84}$ They are becoming janitors, dishwashers, busboys, hotel and hospital maintenance workers, car washers, unskilled construction workers, unskilled nursery workers, and itinerant gardeners. These jobs are characterized by dirty physical labor, wages at or slightly above the minimum wage, low status, low security, and few prospects for advancement.

Cornelius cites economist Michael Piore: "All industrialized economies generate a certain number of low-skill, low-wage, low-status jobs, which nationals of these countries tend to either reject out of hand or accept only under conditions of extreme economic hardship."'85 Cornelius then asks:

Why do jobs of this type continue to exist in the midst of an advanced industrial society? Why are they shunned by native-born Americans? If Mexicans and other foreign migrant workers were not available to fill them, would the jobs continue to exist? If not, what purpose is served by restrictive measures which would attempt to block the access of the foreign migrant to these jobs? ${ }^{86}$

He states that the answer of North and LeBel and the restrictionists-that the jobs exist only because employers have had little incentive to restructure their operations by substituting capital for labor (and thus eliminating the jobs), that the wage scale repels Americans who would take any jobs if the wages were raised high enough, that in any event these jobs are not worth preserving, and that we should not subsidize "marginal, inefficient operations"-is simplistic. ${ }^{87}$

Cornelius agrees with Piore that some of these jobs are built into present patterns of consumption, like the use of china dishes in restaurants. These patterns

82. Id. at 156.

83. W. CORnelius, supra note 45. It should be mentioned that Cornelius studied Mexicans by interviewing a sampling of people in Mexico concerning their experiences in the United States. Therefore, his statistics may not be fully applicable to all undocumented workers or even to all Mexicans; but since all studies indicate that Mexicans are among the least skilled of alien workers, any adverse effects would be most apparent in this group.

84. Id. at $53-56$.

85. Id. at 56, citing Piore, Illegal Immigration in the Uniled States: Some Observations and Policy Suggestions, in Illegal Aliens: An Assessment of the Issues 25-35 (1976), and M. Piore, Undocumented Workers and U.S. Immigration Policy (Sept. 28, 1977) (paper presented at the U.S. Commission on Civil Rights Symposium on Immigration in New York City).

86. W. CORNelius, supra note 45 , at 56 .

87. Id. at $56-57$. 
could be changed, but whether Americans want to change them is questionable. Other jobs are linked to higher-level positions occupied by Americans; elimination of the lower-level job would eliminate the higher-level position, too. Finally, given the capitalistic system under which they operate and the economic cycles which they endure, employers need the power to lay off some workers in slack times. ${ }^{88}$ If they do not have this flexibility, they will go bankrupt. Because these jobs are important to the economy, Piore concludes that they cannot be eliminated, and that restriction of labor supply would simply drive the workers underground into sweatshops and home work paying substandard "cash" wages with no benefits and no tax withholding. ${ }^{89}$

Cornelius points out that there is no research supporting North and LeBel's link between undocumented workers and domestic unemployment. He then cites unemployment rates in the cities where aliens are most numerous as an indication of the lack of a link. ${ }^{90}$ This is weak evidence, however, since unemployment rates are related to so many other variables. Cornelius correctly concludes, "There is simply not enough credible evidence to establish the existence of a cause-and-effect relationship_even an indirect one-between illegal migration and domestic unemployment."91

The claim of depressed wages and working conditions, likewise, has only a grain of truth. In the first place, aside from domestic or food service jobs, many alien workers are unionized and work side by side with U.S. citizens. Only in rare cases does an employer depend almost entirely on alien labor. Generally, the alien workers are treated the same as the domestic workers and are paid the same salaries. In any case, the alien is not a slave. He can always quit his job and find another. The employer who exploits his laborers will not keep them long, whatever their nationalities. Obviously, there are horror stories of Chinese or Hispanic sweatshops, but it must be remembered that these are the exceptions, not the rule. Cornelius points out, "The vast majority of the jobs now held by Mexican migrants - even the illegals-pay at least the minimum wage and usually a good deal more." 92 The thousands of factory jobs in the North and Midwest now filled by aliens are frequently unionized and, at the very least, have standard wages and working conditions. The aliens are hired not because the employer prefers aliens, but simply because they put in a day's work for a day's pay in a job which Americans have come to reject.

Countering North and LeBel's arguments concerning the ability of U.S. industry to introduce labor-saving machinery, substituting capital for labor, Cornelius points out that most employers cannot afford to do this. Most aliens work for firms employing fewer than twenty-five workers-small-scale, labor-intensive businesses such as restaurants, small farms, small construction firms, and small factories producing items such as garments, shoes, or electronic components.

88. Letter from Loy Bilderback, 59 ForEIGN AfF. 940 (1981).

89. Piore, supra note 56 , at 349.

90. W. CORnelius, supra note 45 , at $58-60$.

91. Id. at 60 .

92. Time, May 18, 1981, at 26. 
These companies frequently are subject to intense foreign competition and have small profit margins. They simply cannot relocate or mechanize. ${ }^{93}$ In any case, they are too small to attract U.S. workers looking for a future and not just a job. On the other hand, the larger firms which can substitute capital for labor will either do so or move abroad, in either case resulting in lower employment for Americans. Small or large, Cornelius concludes, the firm deprived of foreign labor will not have jobs to make available to American workers. ${ }^{94}$

While North and LeBel link minority group unemployment in the United States to the presence of alien workers who substitute for American minorities and with whom they cannot compete, Cornelius disagrees entirely. Cornelius states that U.S. workers would rather accept welfare and unemployment compensation (not taxable) than take dead-end jobs paying no more. "The wisdom, as well as the morality, of encouraging unemployed . . . disadvantaged Americans to avail themselves of menial, dead-end jobs which would not even permit the average family to achieve a poverty-level income must certainly be questioned."95 Cornelius states that a restrictive immigration policy will have no effect on the unemployment of minority groups (except to exacerbate it through plant closings and bankruptcies), which is caused by poor schools, lack of skills, poor work attitudes, and racism, as well as the aforementioned income-transfer programs. Cornelius would stress job training to enable the unemployed to gain access to the primary job market. "To the extent that . . . disadvantaged Americans have succeeded in improving their economic situation, it is precisely because they have not remained trapped in the kinds of dead-end jobs typically held by illegal migrants."96

As for North and LeBel's unionization argument, Cornelius asserts that unionization has not been impeded by the presence of illegal workers, and that it is the unions themselves who have shunned the undocumented. ${ }^{97}$ Experience in the garment industry and among farm workers certainly indicates that undocumented workers are as eager for unionization as are legal workers.

North and Le Bel, and Cornelius agree that the presence of more workers, whether legal or illegal, fuels economic growth and creates demand; they disagree principally on the unemployment aspect. In this area, although there is very little research, Cornelius' arguments comport better with common sense and unstructured observation of the economy. Cornelius sums up the results of severely reducing undocumented migration as follows: loss of jobs by American workers resulting from plant mechanizations, relocations, and closings, and from reduced consumer spending; higher rate of inflation as a result of higher prices caused by higher wages; lower rate of economic growth with fewer new job opportunities for U.S. workers as one consequence; and a sharp deterioration of relations with

93. At present, such businesses are foreclosed from relocating abroad. This topic is discussed more fully in Hofstetter, Economic Underdevelopment and the Population Explosion: Implications for U.S. Immigration Policy, LAW \& CONTEMP. Probs., Spring 1982, at 55.

94. W. CORnEliUs, supra note 45 , at 66-67.

95. Id. at 68 .

96. Id. at 70 .

97. Id. at 71-74. 
Mexico, as well as greatly increased poverty in that country. ${ }^{98}$

What is one to conclude from this discussion? The disagreement is, to some extent, one of timing. North and LeBel would close off the labor supply and thus force reorganization; Cornelius and Piore would tamper with the economy gradually, allowing it to determine the need for labor. North and Le Bel's unproven assumptions about opening up jobs to Americans are most vigorously disputed by Cornelius. North and LeBel, and Cornelius agree that all workers should have the same rights, and that the United States should not have a two-class society. North and Le Bel presume that the existence of a secondary labor market necessarily carries with it the existence of second-class workers, but this is not true. Workers in the secondary market can be given the same unionization, wage, and working condition rights as those in the primary labor market. To the extent that our labor laws are strictly enforced, this is achieved. All workers benefit then and, concomitantly, the hiring of illegal aliens becomes less attractive. ${ }^{99}$

This discussion has centered on the labor market effects of undocumented migrants and, if a program is initiated to replace them with legal temporary workers, ${ }^{100}$ its conclusions would also be valid for their replacements. The labor market effects of legal immigration are certainly worthy of mention as well, because half of all immigrants join the labor force, regardless of whether they are officially labeled "workers," "relatives," or "refugees." 101 North and the others who claim alien labor has a deleterious effect on the American economy want immigration levels to be determined by the state of the economy. ${ }^{102}$ Of course, the present regulation of immigration flow into the United States is almost totally divorced from expected labor market effects. Of the 460,000 immigrants legally admitted in 1979, only 17,000 entered with approved occupational preference petitions, the rest entering either as relatives or as refugees. ${ }^{103}$ Thus, the labor certification program for immigrants coming in as workers does little or nothing to protect the American labor market as a whole. North and LeBel would have the total number of immigrants admitted each year depend at least in part on the unemployment rate, with a specific maximum set each year. ${ }^{104}$ This places undue faith in Department of Labor statistics and ignores the time lag involved when predicting the future state of the economy. As Charles Keely points out, ${ }^{105}$ we simply do not have the data and administrative capacity to use immigration to regulate the labor market.

98. Id. at $93-94$.

99. C. KEELY, supra note 4 , at 62 .

100. See infra text accompanying notes 129-137.

101. See D. NORTH \& A. LEBEL, supra note 76; North \& Martin, Immigration and Employment: A Need for Policy Coordination, 103 Monthly Lab. Rev., Oct. 1980, at 47.

102. North \& Martin, supra note 101 , at 47.

103. Statistical Abstract Of THE United States 86, Tables 90, 129, 134 (1981).

104. North \& LeBel, supra note 76 , at $216,225$.

105. C. KeELY, supra note 4 , at 60 . 


\section{VI \\ Responses to Present Immigration Patterns}

Having reviewed the statutory and historical framework and various policy considerations, one may examine the possible responses to the current situation. The first response, that which is presently employed, is simply to do nothing. The advantages are clear: No one will get too angry, and the groups who benefitemployers, aliens, perhaps the American economy-will continue to benefit. Those who suffer from the status quo, such as American minority groups, perhaps, will continue to suffer, however. The political backlash against what is perceived as a critical situation will become exacerbated, and the restrictions which come later will be more stringent and quite possibly more harmful. If it is true that the number of undocumented aliens in the United States is not growing, then there really is no crisis, since legal immigration, including refugees, is adequately controlled by statute. Nevertheless, inaction and silent acceptance of the status quo does not seem likely to continue, given the present political climate.

A second possibility, which has not been tried for the past five or ten years, is enforcement of the present law. The immigration laws were generally enforced from 1952 until the 1970's. Since then, however, the INS budget has not kept up with the number of legal and illegal aliens it has to process. ${ }^{106}$ The bureaucratic and organizational problems of the Service are too well-known to warrant elaboration here, but to a large extent, they are simply caused by a lack of funds. The entire INS budget for fiscal 1980 was $\$ 337,000,000$ - a minuscule percentage of the federal budget. There are too few people attempting to accomplish far too much work.

The entire Border Patrol consists of 2,200 agents, ${ }^{107}$ and since the border must be manned twenty-four hours a day, 365 days a year, only 400 agents are on duty along the entire Mexican border at any one time. Leonel Castillo, former INS Commissioner, testified in 1978 that "more than 50\% of the entries that are made into the United States without documents are made at or near three locations: San Diego, California, El Paso, Texas, and Yuma, Arizona."108 A little more enforcement at these places would go a long way. Some would-be immigrants will walk across the Mexican and Arizona desert to gain entry at little-used and littlepatrolled points, but they are few in number because of the dangers and since aerial surveillance is much easier in open areas. When this writer began practicing immigration law in the late 1960's, if a visitor were denied an extension of stay, he would shortly thereafter receive a letter from the INS asking him to come in for an interview, at which time he would be advised to leave. Although the investigations branch was never sufficiently manned to chase after many of those who did not appear for the interview, the very receipt of the letter frightened many aliens into

106. According to the House Government Operations Committee, the INS had to consult aliens' files $5,700,000$ times in 1977 and $14,800,000$ million times in 1981. Meanwhile, in the entire past decade the INS staff increased by only 32\%. U.S. NEWS \& WORLD REPORT, June 22, 1981, at 27, 29-30.

107. Statistical Abstract of the United States 92, Table 142 (1981).

108. Immigration to the United States: Hearings before the House Commiltee on Population, 95th Cong., 2d Sess. 139 (1978). 
leaving at the end of their authorized stays and established the INS as having at least some control of the situation. Today, any visitor can stay indefinitely, without fear of receiving such a letter, much less being sought after. Our controls in this area are clearly nonexistent; this is a direct result of a lack of money for personnel and computerized equipment.

Similarly, our information about arrivals and departures is in chaos. Recently, I had a client who had been asked to prove her entry into Costa Rica. She wrote to the immigration authorities in that country and received a computerized printout giving her name, date of departure and flight number, and date of return and flight number. The same information regarding departures from the United States does not exist, and the information about arrivals often cannot be located in the INS files in Washington. ${ }^{109}$

The purpose of these examples is merely to point out that the situation is not impossible. The INS is simply underfunded and undermanned. Its employees, by and large, are conscientious and diligent. They are understandably frustrated by the increasing number of complaints and the decreasing amount of funding given them with depressing regularity. ${ }^{10}$ This is the exact opposite of the approach that should be taken. The INS undeniably needs more personnel, more equipment, and more money-not less. Before making wholesale changes in a system it would be preferable to give the present system an opportunity to demonstrate whether it can work. The INS has not yet been given such a chance.

\section{VII}

\section{Recent Proposals to Revise the Immigration LaW}

Another approach toward resolving the current immigration problem is complete revision of the law. President Carter appointed the blue-ribbon Select Commission on Immigration and Refugee Policy (SCIRP) to study and review the entire immigration law. After two years of work, SCIRP released its report. ${ }^{111}$ In the words of Governor Bruce Babitt of Arizona, "The badly-divided Select Commission's preliminary recommendations reflect a mixture of contradictory solutions, uneasy compromises and old ideas . . ."."112 Both the Commission and later proposals by the Reagan Administration focus on three major changes: amnesty, employer sanctions, and a guestworker program. The Simpson-Mazzoli bill includes amnesty and employer sanction provisions, and eliminates only the guestworker program.

The current law already contains a provision offering a type of amnesty called

109. This information is based on personal experience with the INS form used to request replacement of a lost arrival document. The INS frequently cannot locate its copy and thus verify the arrival.

110. U.S. NEWS \& WORLD REPORT, June 22, 1981, at 27, 29-30.

111. Staff of Select Comm'n on Immigration and Refugee Policy, 97Th Cong., ISt Sess., Final Report: U.S. IMMIGRATION AND the NATIONAl INTEREST (Comm. Print 1981). The final report and recommendations, with supplemental views by commissioners, was submitted to Congress and the President on March 1, 1981.

112. Address by Bruce Babitt, Policy Implications of Illegal Immigration from Mexico, Joint Meeting of the Association of Immigration and Nationality Lawyers and the State Bar of Arizona (Jan. 23, 1981) [hereinafier cited as Babitt], reprinied in 58 INTER PRETER RELEASES 175. 
"suspension of deportation."113 Under this section, permanent residence is available to any alien who has been physically present in the United States for seven years, who has demonstrated good moral character during that time, and who can establish a case for "extreme hardship" if forced to depart. In practice, the INS and the courts have been quite strict and unyielding in determining extreme hardship. They have generally required a showing that many of the alien's family members reside in the United States and few abroad, that the alien be ill or of advanced age, or that some other very special situation exists. ${ }^{14}$ The courts have consistently held that neither seven years of mere physical presence nor "mere economic hardship" is sufficient. 115 One simple way to achieve a limited amnesty for many deserving cases would be simply to remove the word "extreme" from the hardship requirement. This change would signal the intention of Congress to liberalize greatly the availability of this remedy. Is a more drastic change necessary? Under this proposed change, the grant of amnesty would be left for the INS and the courts to decide on a case-by-case basis, which is as it should be. Certainly some aliens who reside here seven years would not suffer any real hardship in having to leave, and there is no reason why they should be rewarded with amnesty merely because the INS was too understaffed to find them.

On July 30, 1981, the Reagan administration announced its immigration proposals, ${ }^{116}$ recommending that illegal aliens who had arrived before January 1 , 1980 , be granted a status of "renewable term temporary resident." After ten years of continuous residence in the United States, a temporary resident could apply for permanent resident status if he could demonstrate English language capability. ${ }^{117}$ The Simpson-Mazzoli bill ${ }^{118}$ originally proposed full amnesty for those physically present since January 1, 1978, with temporary resident status for those here since January 1, 1980, convertible to permanent residence after two years. ${ }^{119}$ During Senate consideration, the date for full amnesty was amended to January 1, 1977, and the period for conversion of temporary to permanent resident status increased to three years. ${ }^{120}$

All of the time periods proposed are so brief that they will encompass many for whom amnesty is not really a pressing desire. As Jorge Bustamante and Wayne Cornelius point out, most Mexican workers want only seasonal work and return to their families each year. ${ }^{121}$ For these individuals, amnesty is irrelevant. Blanket amnesty would also serve to increase the flow of undocumented workers who

113. Immigration and Nationality Act, 8 U.S.C. $\$ 1454(a)$ (1976).

114. See generally C. Gordon \& H. Rosenfield, Immigration LaW and Procedure $\S 7.9$ (e) (1959).

115. Id.

116. N.Y. Times, July 31,1981 , at 1 , col. 6 .

117. These proposals appear as Title I of the Reagan Administration bill, S. 1765 and H.R. 4832, 97th Cong., 1st Sess., 127 Cong. REC. S11991, H7729 (daily ed. Oct. 22, 1981).

118. S. 2222, 97th Cong., 2d Sess., $\$ 301,128$ Cong. Rec. S2216 (daily ed. Mar. 17, 1982).

119. Id.

120. Compare $\S 301$ of S. 2222 as introduced, 128 CoNG. REC. $\$ 2219$ (daily ed. Mar. 17, 1982) with the final version, 128 CONG. REC. S10628-29 (daily ed. Aug. 17, 1982)). 26

121. Jorge Bustamante, Professor of Sociology at Colegio de Mexico, quoted in TiME, May 18, 1981, at 
might assume that another amnesty would be forthcoming some day, and would prompt an enormous market in false documentation of U.S. residency, further taxing the meager resources of the INS. Finally, amnesty rewards those who arrived or remained illegally while at the same time it bars from consideration those students or temporary workers who have maintained legal status and now wish to remain in the country. In effect, this policy puts the illegals ahead of those who are patiently waiting their turns on the waiting lists and thus mocks our professed desire to encourage obedience to the law.

The proposals supporting temporary status for those here before January 1 , 1980, are both too little and too much. Legalizing the status of someone here only since 1979 is too generous by far, while the status being offered-the right to work and pay taxes but with almost complete preclusion from all federal and state government benefits, ${ }^{122}$ and no right to bring spouse or children-is far too restrictive. An amnesty, if one is declared, should be easily administered. The proposal will create a second-class status for millions of aliens. If they truly have sufficient stake in the United States to merit amnesty, the amnesty should be full, not partial.

In sum, amnesty is not a desirable solution; the better approach would be to liberalize the suspension of deportation provisions, and to make the grant of such a suspension an expeditious administrative proceeding rather than the current dilatory quasi-judicial hearing. Similarly, the period of residence required could be significantly shortened.

The second major proposal in the SCIRP report, also accepted by the Reagan Administration and the Simpson-Mazzoli bill, is the institution of sanctions against employers of unauthorized workers. ${ }^{123}$ Although SCIRP could not agree on a type of identity card which would enable the employer to determine the legality of the worker, the Reagan plan calls for the employer to examine any two pieces of identification-including birth certificate, driver's license, and Social Security card. It also requires the employer and employee to sign a declaration certifying that the worker is legally allowed to work and that the employer has examined the documents and has no reason to doubt the alien. The use of such easily forged documents means that the employer who wants to hire undocumented aliens need not fear prosecution, while the one who wants to discriminate against certain ethnic groups will be able to use the excuse that the applicant's documentation was not sufficient or not trustworthy.

The fears that some employers will use sanctions as an excuse for discrimination against minority groups, especially Hispanics, cannot be dismissed. It is already difficult for many Puerto Ricans and Chicanos to prove their place of birth, and it is certain that many "legal" workers will be late in obtaining their identification; some will be either dismissed or refused employment for lack of documentation. Hiring is already a very subjective process, despite the laws against discrimination; it is obvious that both the opportunities and the reasons for discriminatory hiring would both increase greatly under the proposed employer sanc-

122. S. 2222, 97th Cong., 2d Sess., 128 Cong. Rec. S10629 (daily ed. Aug. 17, 1982).

123. Id. at $\$ 10619-20$ (the proposals appear as $\S 101$ of $\mathrm{S}$. 2222); see also supra note 116. 
tions. The white American who speaks without an accent has nothing to fear; the one with an accent, or a strange surname, or a different color skin will certainly be scrutinized more carefully and, in cases of similar qualifications, the white nonethnic will be the most likely to be hired. Given that he can never be sure whether the document being presented to him is valid or bogus, how can an employer be blamed for an excess of caution?

An alien not authorized to work cannot now legally acquire a Social Security card. As a result, there is now a specialized black market for false cards. Other undocumented workers use the cards of friends or relatives, or simply make up numbers to give their employers. Nonetheless, to my knowledge no one has ever been prosecuted for merely using a false Social Security card, since few juries would convict someone for merely trying to get a job. The proposed sanctions would not change this situation much.

Another serious effect of the imposition of sanctions would be a drop in tax revenues. Almost all employers presently deduct taxes for their unauthorized workers presenting Social Security cards or even false numbers. Sanctions would force an increased resort to the "underground economy" of no payroll records and no pay checks, with a consequent loss of tax revenues.

One final problem may arise if the employer who has "unwittingly" hired an undocumented worker is confronted by the worker, who admits that he lied, and asks the employer to sign his labor certification application. Is the fine applicable whenever the employer learns of the forged documents, or only at the time of hire? If the former, the law may well penalize an alien who by definition is not taking the job of an American, by making it impossible for him to obtain a labor certification.

What, if anything, would be gained by the institution of this system of sanctions which, as Governor Babitt indicates, involuntarily deputizes employers as agents of the government? ${ }^{124}$ As mentioned earlier, it is far from clear that undocumented workers are really taking jobs from Americans, yet the only goal of the sanctions must be to free jobs for Americans. But what jobs-menial tasks such as washing dishes? At a slightly higher level, that of household work or semiskilled factory jobs, it is frequently possible to obtain certification from the Department of Labor that there is no American ready, able, willing, and available to take the job. These workers are not taking jobs from Americans, and sanctions therefore will not open up these jobs to Americans without tremendous dislocations in the economy, inflationary price rises, and closings or overseas relocations of factories. One would think the Reagan Administration, with its commitment to a free market, would recognize this fact and not try to tamper with it. Why should marginal small businesses be the guinea pigs for an unnecessary experiment which may well be disastrous if it works, and merely unfortunate if it does not?

In addition to being economically unwise, employer sanctions would be a dangerous first step toward a significant loss of civil liberties. On this point, however, one cannot hope for too much sensitivity from the present administration or

124. Babitt, supra note 112 , at 176 . 
Congress. As Senator Simpson of Wyoming states, "If there is nothing else I get done, I intend to send a signal to the world that you have to have some kind of identification before you work here. Right now we are the patsies of the earth."125 Yet it is one of the glories of the United States that we have so few controls over life. Compared to most countries, we are mercifully free of bureaucratic controls over who may work, who may open a business, and where one may live. Many new immigrants, even those from "free" countries like those of western Europe, are amazed at the degree of freedom to be found here. It cannot be doubted that the intense interest among foreigners (not only those from Latin America and Asia, but also those from Europe) in investing and settling in the United States, is based not only on their view of the United States as the last bastion of economic freedom on earth, but is in large measure linked to this country's relative freedom from bureaucratic controls. The imposition of employer sanctions would be a giant step in the opposite direction. This administration, so committed to a freer economy and less regulation, should be loathe to establish sanctions which will not even be effective in making more jobs available to Americans, but will merely encourage discrimination.

There is, of course, another more cynical interpretation of the Reagan administration's sanctions proposal. Perhaps, by allowing the employer to escape liability by checking already existing and easily forged documents and by keeping the fine to a relatively low $\$ 500$ to $\$ 1,000$, the administration is deliberately proposing a law which will be impossible to implement strictly. Many foreign countries already have employer sanction laws which have proven to be impossible to enforce. ${ }^{126}$ If this is the case, the net economic effect may not prove harmful, but the discriminatory effect may well be.

It is possible that fear of public opinion is swaying the administration and Congress to propose sanctions. The news media has been filled with items concerning immigration and the alleged crisis. Recent polls indicate that $65 \%$ of all U.S. citizens want the total number of immigrants reduced, ${ }^{127}$ and that $76 \%$ are in favor of banning the hiring of undocumented workers. ${ }^{128}$ Popular opinion is affected greatly by the media, and Congress should not lose sight of the fact that many ethnic groups are more committed to immigration than they are to clean air, more space, or other environmental goals. Perhaps the problem would move to the back

125. Time, May 18, 1981, at 27 .

126. According to a General Accounting Office Study released on September 29, 1982, employers in the 20 foreign countries studied were usually able to evade responsibility, and the penalties actually applied in those cases which were prosecuted successfully were too small to deter the hiring of undocumented aliens. Strict legal restraints on investigations, lack of personnel, and noncommunication between government agencies all impeded enforcement; all three are present in the United States as well. N.Y. Times, Sept. 30, 1982, at A20, col. 1.

127. Associated Press-NBC News Poll, cited in Newsday, Aug. 17, 1981, at 12, col. 4. On the other hand, perhaps public opinion is becoming less restrictionist; the Roper Poll of June 1980 reported $80 \%$ in favor of reducing immigration.

128. Gallup Poll, ciled in TIME, May 18, 1981, at 27. (This result has always seemed to me to be a good example of a question guaranteed to elicit a "yes" response. One always has a nagging feeling that many of the respondents did not really understand the question, much less its implications, and that the pollsters certainly were not going to give any explanations.) 
burner if Congress took any action, even a "housekeeping" bill of minor changes, and proclaimed it a victory.

\section{VIII}

\section{The Temporary Labor Program}

One apparent response to the realization that aliens perform useful services in our economy has been the proposal for some type of temporary or "guestworker" program-admission of a limited number of workers, subject to controls over their place of employment, their wages, and their working conditions. The guestworker idea has been popular in Europe ${ }^{129}$ and has been used, with poor results, in the American Virgin Islands. ${ }^{130}$

According to current estimates, temporary workers number about 20,000,000 worldwide. ${ }^{131}$ Approximately one-half are legal. Many would gladly opt for permanent residence, but opportunities are extremely limited-only 1,000,000 per year world-wide, about half of which are in the United States. This fact alone should give us pause in considering whether we need a guestworker program in addition to our liberal permanent-residence program. Generally speaking, the guestworkers fill the same slots in the economy as do undocumented workers positions in labor-intensive industries not desired by domestic workers for a variety of reasons.

Unfortunately, experience indicates that the temporary labor supply turns out to be permanent, and thus the guestworker plan fails. European countries have been attempting to repatriate their guestworkers for years, yet millions remain. The first wave of workers brought their families, and restaurants and ethnic businesses sprang up to service the growing population. A growing core of guestworkers acquired financial and personal equity in the receiving society and no longer saw themselves as temporary residents. The children of these workers were not satisfied with their parents' jobs, and " $t]$ he host nation finds itself again on a labor importation treadmill. In turn, each round of immigration results in more permanent residents, but fewer workers willing to fill undesirable jobs." 132

Some analysts, such as Charles Keely, ${ }^{133}$ propose a temporary labor program in which the workers would be admitted to work in regions and sectors identified by the Department of Labor as needing manpower. Yet the Department of Labor is notorious for refusing to recognize the need for foreign labor, ${ }^{134}$ and the adminis-

129. "Western Europe admitted over 30,000,000 workers for temporary employment . . . between the mid-1950's and the early 1970's." Hewlett, supra note 39 , at 369 .

130. D. NORTH \& A. LE BEL, supra note 76 , at 180 , cite a "multiple layering of that society, with whites and native-born blacks holding the upper hand . . . . Nonimmigrant workers there not only have fewer rights in the labor market, . . . but are subject to various other kinds of discrimination as well."

131. Martin \& Richards, Intemational Migration of Labor: Boon or Bane, 103 MONTHLy LAB. REV., Oct. 1980 , at 4. They define "guestworkers" as people working where they are neither citizens, nor permanent residents, nor intended permanent residents.

132. Id. at 7 ; see also Hewlett, supra note 39 , at 370 .

133. C. KEELY, supra note 4, at 60.

134. For example, there is a constant struggle between U.S. apple growers and the Department of Labor over how many West Indian temporary workers to admit each year to harvest the apple crop; theoretically, Americans should be available for this physically demanding job, but few apply. 
tration and policing of such a program would be a nightmare. If, as Keely proposes, the workers are allowed to bring their families and are entitled to government benefits, there is an increased likelihood that they will become permanent residents, as happened in Europe. As Walter A. Fogel points out, "[W]orkers just don't like to see themselves as commodities, and they do not want to return."135 Strange as it may seem, the present situation in the United States may actually be preferable. Since the undocumented temporary worker rarely has his family with him and is entitled to no government assistance, he is much more likely to consider himself truly temporary.

There is also a moral objection to a guestworker program. Guestworkers are treated as second-class citizens, without the rights of other workers-they frequently are not even allowed to leave their jobs if dissatisfied. Their situation is worse in this respect than that of the undocumented worker, who at least is generally conceded the protection of our labor laws, including the right to join a union and the right to strike. The guestworker cannot plan a career. Even worse, his exploitation is with government sanction and, not infrequently, government intervention. Moreover, the jobs performed by guestworkers are labelled as "foreign" and natives will not do them. Thus, the presence of guestworkers creates a need for more guestworkers to do these "foreign" jobs. Under the current situation in the United States, although some positions may be occupied largely by alien labor, at least there are no jobs officially labelled as such. The possibility remains that the job will be filled at some point by an American or legal resident, especially if the gradual upgrading of the wages and/or working conditions (combined with the gradual tightening of the labor supply) makes the job more attractive. With a guestworker program, the possibility of upgrading jobs is much less.

Although President Reagan called for a large-scale guestworker program for hundreds of thousands ${ }^{136}$ while campaigning in Texas in September 1980, the Reagan Administration's official proposal was watered down to a 50,000 per year two-year pilot program. ${ }^{137}$ The Simpson-Mazzoli bill wisely eliminates the program entirely. It would be no panacea and indeed might exacerbate the exploitation of alien workers. It should not be revived.

\section{IX}

\section{IMPROVING THE PRESENT System}

The foregoing discussion has focused on some major issues in immigration policy. But whether there are to be sanctions, amnesty, or guestworkers, the questions of specific numbers and ratios remain. These are, of course, truly political questions which will be debated and ultimately decided in Congress, but some guidelines can be noted.

The first question which must be answered is how many aliens should be

135. Fogel, The Moral Dimensions of a Temporary Worker Program, Center MAG., Sept.-Oct. 1979, at 13. The foregoing analysis owes much to Mr. Fogel's article.

136. Hewlett, supra note 39 , at 367 .

137. See supra note 116. 
admitted for permanent residence. Most current proposals suggest maintaining the current limit of about 450,000 immigrants per year (270,000 plus immediate relatives, plus 50,000 refugees, plus some "emergency" refugees). ${ }^{138}$ Any figure in the range of 400,000 to 800,000 is sensible from the standpoint of population growth. Having chosen the number, how are the visas to be parcelled out? How many refugees should be admitted, and, if an extraordinary number of refugees are admitted, should the government delay the admission of a number of regular immigrants? To do so would be patently unfair to those who have been waiting on the regular waiting lists, and would amount to a preference for refugees above all others.

The question of workers versus family members remains. The current law reserves only $20 \%$ of the visas for those immigrating as workers, although the labor certification requirement establishes a qualitative barrier which keeps the waiting lists in this category fairly small. It is thus not necessary to increase the worker categories much, if the labor certification requirement is to be kept. As the law stands now, visas not used by the third-preference category (which consists of all professionals plus artists and scientists of distinguished merit and ability) cannot be used by the sixth-preference category (all other workers). The third-preference category is generally undersubscribed, and the sixth is oversubscribed. ${ }^{139}$ One useful change would be to combine the third and sixth preference categories into one category for all types of workers.

The labor certification requirement is perhaps more important as a symbol than as a protection for the labor market. Theoretically, it could be replaced by a system of admission based on skills (without requiring a specific job offer), which also would reduce the necessity for illegal work in order to get a sponsor for a labor certification in the first place. ${ }^{140}$ The net effect would probably be the same,

138. The Simpson-Mazzoli bill sets the limit at 425,000 (350,000 relatives and 75,000 "independent" immigrants), plus refugees and, of course, those to be granted amnesty. S. 2222, 97th Cong., 2d Sess., 128 CONG. REc. S10624 (daily ed. Aug. 17, 1982).

139. The Simpson-Mazzoli bill divides the independent category as follows: Doctoral degree holders and those with exceptional ability in the sciences, arts, or business who will benefit the national economy, cultural or educational interests, or the general welfare of the United States, are given the first opportunity at the 75,000 visas. (Unfortunately, "exceptional ability" is undefined). After them, preference is given to skilled workers; then, investors of 250,000 dollars or more who will employ four U.S. workers (but not to exceed 7,500 visas per year), and finally, the catchall nonpreference category which gets any remaining visas. Id. at $\mathrm{S} 10625$

140. As this author pointed out in 1975,

In order to obtain labor certification, the alien . . . must have a specific job offer from a prospective employer. The alien's qualifications for his particular job, the lack of Americans in that job category who are able, willing, qualified, and available, and the effect of the alien's proposed terms and conditions of employment must all be approved. Obviously, it is not easy for an alien to learn of a job opening, and to obtain an offer for it, while abroad. Still less likely is it that the prospective employer will be willing to file a set of papers with the Labor Department-and possibly haggle with them over job requirements and wages_on behalf of an alien whom he has never met, for a job to be taken two or three years later when the alien is finally admitted. As a result . . . aliens by the thousands enter the United States with visitors' visas forbidding them to work, and then seek and obtain job offers and illegally fill those jobs while awaiting their immigrant visas. When the visa is available, they return home briefly to receive it from the consul, and are back at work here in the United States soon after. It therefore appears that the requirement that the alien have a specific job offer (rather than simply be qualified in a job area known to be short of personnel) and the long delays in obtaining a visa combine 
except for those workers who have specialized skills which might fall through the gaps in the list of desired skills; these people can now get labor certifications but would not get admission based on skills. Perhaps the two should be combined, with an expanded list of occupations offering automatic labor certification. ${ }^{141}$ The labor certification is one of the few ways a "new seed" alien can now immigrate to the United States and should probably be retained in some fashion.

Regarding the question of temporary as opposed to permanent workers, the author's conclusion as to the inadvisability of a temporary worker program has already been discussed. Moreover, it is one of the positive features of American immigration law that workers are seen as worthy of a grant of permanent residence and not as second-class citizens treated as commodities under a guestworker program.

The present system does not adequately cover prospective immigrants who are investors and retirees. Previously, "nonpreference" visas were available for these categories of "new seed" immigrants. One easy response to the current lack of nonpreference visas would be to reserve some visas for nonpreference applicants. Alternatively, investors of substantial sums of money could be accommodated by the present third-preference category. Parents of legal residents, a group with no preference through an egregious and probably unintended lapse, could be accommodated by the present second-preference category, perhaps in exchange for married brothers and sisters of U.S. citizens if the family preferences are thought to be taking too many visas. This solution has the disadvantage of not accommodating retirees who are not the parents of legal residents. Since retirees will not be entering the labor market, and since very few of them will have young children, their net effect on the U.S. economy will be as consumers. Therefore, the first solution, which would provide a definite number of visas for the nonpreference category, seems preferable. ${ }^{142}$

Present proposals retain the 20,000 per country limit, although the necessity for this limit is not apparent. If we are to have a system which is not based on national origins, why should Filipinos or Koreans in certain work or family categories have to wait longer than immigrants from other countries, just because many of their compatriots also wish to come? Does it really matter if we admit a Pakistani instead of another Indian, or a Salvadorean instead of a Mexican? The numbers are small enough that this limit, based on fear of massive immigration from one country, should be lifted. We certainly tolerate 30,000 or even 40,000 immi-

to make illegal immigration and employment helpful if not necessary steps in the pursuit of permanent residence in the United States.

Abrams \& Abrams, Immigration Polig-Who Gets in and Why, PuB. INTERest, Winter 1975, at 3.

141. The Simpson-Mazzoli bill provides that "the Secretary of Labor may use labor market information without reference to the specific job opportunity . . ." and that the lack of qualified workers must be a nationwide shortage, S. 2222, 97th Cong., 2d Sess., 128 CONG. REC. S10626 (daily ed. Aug. 17, 1982). Moreover, it is not yet clear whether the Department of Labor would, under this section, be free to use local market data or specific job characteristics in making determinations if they should so desire.

142. The Simpson-Mazzoli bill specifically accommodates investors but not "nonpreference" applicants, who will receive visas only if preferred categories do not use up the available visas. Parents of legal residents get no special consideration, and unmarried adult sons and daughters of legal residents are eliminated. Id. at $\mathbf{S 1 0 6 2 5 .}$ 
grants in one year from one country, without destroying the diversity of the immigrant flow. The Reagan administration and the Simpson-Mazzoli bill propose doubling the Mexican and Canadian quotas to 40,000 each, and allotting unused Canadian visas to Mexico, thus providing about 65,000 visas per year to Mexico. ${ }^{143}$ This proposal will relieve the present Mexican backlog, but only at the expense of the rest of the world.

\section{$\mathrm{X}$}

\section{CONCLUSION}

If this article has seemed to descend from the theoretical level of policy-making to the practical or even the picayune, it is because major changes in immigration law are not necessary at this time and a "housekeeping" bill of minor changes in conjunction with greatly increased funding for the INS would be sufficient to meet the current overstated "crisis." The current administration-especially since a conservative one-should realize that there are advantages to retaining a system that is familiar and works (albeit creakingly) and that replacing it with untried solutions may well create more problems than it solves.

No changes can eliminate the irreconcilable conflicts of immigration policy. The goals we acknowledge_primarily, reuniting families, and secondarily, admitting needed workers and refugees_are themselves in conflict because immigrants in all categories must share a limited number of visas. Other goals, such as encouraging investment or retirement, or limiting population growth, make the choices even more difficult. As Michael Teitelbaum aptly stated, this is truly a case of "right versus right."144

It is important, however, to distinguish criticisms of various aspects of our present statutes and administrative procedures from criticism of our basic immigration policy. The fact is that of all the world's countries, the United States remains the most hospitable to immigrants. We accept more immigrants than any other country, without regard to religion, race, color, or national origin. Moreover, in comparison with other countries receiving large numbers of immigrants, we accept them willingly; prejudice against newcomers is rare and opportunity for economic and social integration is great.

None of this is news to the millions of aliens now planning or aspiring to, a future in the United States. Though some Americans may view our society as racist or oppressive, this country remains a symbol of political freedom, social mobility, and economic opportunity to much of the world. The difficulties we face in establishing and implementing an immigration policy are not the result of incompetence or intolerance. On the contrary, we face difficult choices because our country remains immensely attractive to enormous numbers of aliens, and because we are willing to admit a substantial number of them. Major revisions of our immigration laws, such as imposition of employer sanctions-a deliberate attempt to decrease vastly and suddenly the access of American employers to for-

143. Id. at S10624-25; see also supra note 116.

144. Teitelbaum, supra note 50. 
eign labor-may reduce the economic and social well-being of the country, with adverse consequences for citizens as well as for aliens. Let us proceed slowly. 
